

Technological University Dublin ARROW@TU Dublin

2010-01-01

\section{Towards an Understanding of International City Break Travel}

\author{
Gerard Dunne \\ Technological University Dublin, gerard.dunne@tudublin.ie \\ Sheila Flanagan \\ Technological University Dublin, sheila.flanagan@tudublin.ie \\ Joan Buckley \\ University College Cork, jb@ucc.ie
}

Follow this and additional works at: https://arrow.tudublin.ie/tfschhmtart

Part of the Urban Studies and Planning Commons

\section{Recommended Citation}

Dunne, G., Buckley, J and Flanagan, S (2010) Towards an understanding of international city break travel. International Journal of Tourism Research, Vol 12 (5), pp 409-417. doi:10.1002/jtr.760

This Article is brought to you for free and open access by the School of Tourism \& Hospitality Management at ARROW@TU Dublin. It has been accepted for inclusion in Articles by an authorized administrator of ARROW@TU Dublin. For more information, please contact arrow.admin@tudublin.ie, aisling.coyne@tudublin.ie, gerard.connolly@tudublin.ie.

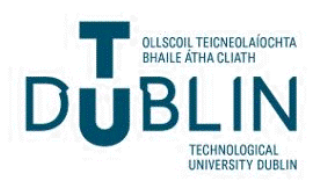




\section{Towards an Understanding of International City Break Travel}

\section{INTRODUCTION}

The focusing on cities for leisure breaks, particularly international leisure breaks, has become a contemporary travel phenomenon that has resulted in the enhancement and rejuvenation of many urban areas throughout Europe. Cities are moving centre stage, providing a leisure experience for travellers that is both diverse and immediate.

According to IPK International's European Travel Monitor, European city tourism grew by $20 \%$ in 2005 , compared to an increase of just $3 \%$ in sun and beach holidays (Freitag, 2006). However, while urban tourism in general has received increased academic interest over the past two decades (e.g. Buckley and Witt, 1985; Jansen-Verbeke, 1986; Ashworth and Tunbridge, 1990; Ashworth, 1992; Law, 1993, 2002; Page, 1995; Mazanec, 1997;

Judd and Fainstein, 1999; Pearce, 2001, Hall and Page, 2002; Wöber, 2002; Selby, 2004) analysis of the specific visitor groups that make up urban tourism demand has been less forthcoming. With a few notable exceptions, little research specifically relating to city break travel currently exists. Indeed most of the commentary on the subject has tended to emanate from industry sources or consultant reports. Little academic research explicitly addressing city break travellers and city break trip-taking currently exists. This indicates a significant gap in the urban tourism knowledge base.

\section{CITY BREAKS - A DISTINCTIVE TYPE OF TRIP}

A city break represents a distinctive type of holiday, one that Trew and Cockerell (2002, p.86) define as, 'a short leisure trip to one city or town, with no overnight stay at any 
other destination during the trip.' This definition importantly highlights the 'city only' nature of the trips and provides a basis on which to segment such visitors. Indeed segmenting visitor markets along the lines of type of trip can be very effective, particularly for destination management bodies. Such breakdowns generally offer potentially more valuable data than traditional socio-demographic classifications that, as Bieger and Laesser (2000, p.56) point out, are 'increasingly less helpful for the segmentation of guest groups.' As researchers begin to recognise the significance of type of trip in understanding visitor behaviour (Sung et al., 2001; Bloy, 2000; Hudson, 1999) it has become more important to focus attention on the characteristics of different holidays and highlight the distinctiveness between them. Sirakaya and Woodside (2005) describe type of trip (including aspects such as travel party and duration) as being a crucial factor in people's travel decision process. Examining the city break trip in terms of its distinctive elements is therefore both useful and important in the context of urban tourism research.

\section{GROWTH OF CITY BREAK TRAVEL}

There are a number of factors that can be attributed to the rising popularity of city break holidays in Europe. Firstly, the increased availability of low cost air travel with its emphasis on short haul, point to point journeys is undoubtedly a significant contributor. This development has made a wide range of city destinations accessible at lower cost. Secondly, there is the increased tendency of Europeans to take additional but shorter holidays. This is an important characteristic according to Trew and Cockerell (2002) who point out that in some European countries overall leisure intensity - i.e. the proportion of 
the population travelling at least once a year - is reaching a ceiling. At the same time, the total number of trips taken per market continues to grow, as people opt for two or more trips a year in place of, or in addition to, their main annual holiday.

Another reason for the growth relates to people's changing perception of cities as travel destinations. For contemporary travellers the city has increasingly become viewed as, not just an entry, exit or transit point, but a desired destination in its own right.

Finally, the increasing role of the internet in the travel decision making process has also contributed greatly to the city break phenomenon. The ease with which people can access information and make bookings online has greatly facilitated this form of travel. The uncomplicated nature of most city break trips (the majority consisting of just two components, transport and accommodation) reduces the risk element commonly associated with booking holidays online.

These factors have all contributed to the steady growth of 'city only' holidays and have resulted in city break travel delivering much welcome intra regional traffic at a time when Europe's market share of global tourism is falling. The city break phenomenon has helped to popularise and regenerate several European cities, breathing new life into many beleaguered post industrial urban economies. It has also given rise to a number of 'new' city destinations that have emerged in response to the enthusiastic demand for additional city break locations. Tallinn, Bratislava and Riga are among a new group of cities in recent years to have established themselves on the European city break travel map. The value of this form of tourism is not lost on the product providers within the cities themselves. Accommodation suppliers in particular appreciate the propensity of city break travelers to book rooms at weekends thus complementing the weekday occupancy 
that they traditionally receive from business travellers. In addition, the all year round arrival pattern commonly associated with city breakers is seen as a significant positive factor for businesses that operate in such a seasonal industry.

\section{CONCERNS IN RELATION TO CITY BREAKS}

The city break phenomenon, although generally welcomed by urban tourism destinations, has nonetheless received a measure of criticism from certain quarters in recent years. Some of this relates to the type of tourists commonly attracted to this form of travel, particularly where low cost airlines are involved. For example, in recent times the residents and homeowners of Deauville in Normandy tried to stop the arrival of cheap Ryanair flights from London, believing such a development would encourage an influx of downmarket, short break travellers to their traditionally upmarket resort town. Similar criticisms have also been raised in other destinations, particularly in a number of emerging Eastern European cities where stag parties and other relatively invasive forms of tourism account for a significant proportion of the city break traffic.

One of the most pressing issues relating to city breaks concerns the impact the phenomenon is having on regional and rural tourism. There is a fear in some quarters that popular city destinations are 'taking' potential tourists from more traditional non urban holiday areas. This is certainly the case in Ireland where significant dissatisfaction exists among regional tourism bodies at the perceived loss of business due to the increasing popularity of Dublin city. According to a report by the Irish Tourism Industry Confederation on visitor distribution in Ireland, between 2000 and 2005 the number of nights spent by international holidaymakers in Dublin increased by $39 \%$ while the 
number of bednights spent in the rest of the country declined by almost $11 \%$ (ITIC, 2006). This highlights a fundamental change in the spatial spread of visitors to Ireland and one which is clearly worrying the country's tourism authorities. However, a critical question seems to be whether or not cities are actually 'taking' visitors from other regions, or whether it is just a case of fewer people wishing to visit rural or regional destinations.

Another criticism commonly levelled at city break travel relates to the green issue. Significant attention is now being focused on airlines, particularly low cost carriers, in terms of their contribution to carbon emissions globally. Non essential, supplemental trips such as city breaks are increasingly being disapproved of by a growing environmental lobby. As governments begin to levy green taxes on the transport sector and as people become increasingly aware of their carbon footprint it will be interesting to see if this has an impact on the demand for city break travel.

\section{METHODS}

In examining the distinctiveness of the international city break market to Dublin it was decided to use a combination of quantitative and qualitative methods. Within the combined methods design, a sequential triangulation approach, as outlined by Millar and Crabtree (1994), was considered particularly suitable. This consists of conducting two phases to the research project, with the results of the first phase essential for the planning of the next. A quantitative study was undertaken first (Phase One), which provided essential data in relation to the characteristics of city break visitors and their trips, in addition to information necessary to carry out the second phase. Phase Two involved an 
in-depth qualitative analysis that examined aspects of city break visitor's consumer behaviour. Both phases combined to provide a unique insight into city break travel characteristics and behaviour.

Phase One involved a face to face survey carried out in Dublin where one thousand overseas visitors were intercepted over a twelve month period at locations across the city centre. From this sample two main visitor cohorts were identified and separated. These were, city break holidaymakers $(n=379)$ and non-city break holidaymakers $(n=416)$. The former were defined as leisure visitors who were visiting the city only. The latter consisted of leisure visitors who were visiting Dublin as part of a wider holiday (i.e. the city was just one part of their trip).

Having isolated both visitor segments it was possible to carry out a comparative analysis. This proved very useful in identifying distinctive characteristics and features of the city break market. It should be noted, only commercial city breaks were considered therefore people visiting family and friends were not included. In addition, only those who visited the city for the entirety of their trip were deemed to be city breakers (as per Trew and Cockerell's definition).

Phase Two consisted of 40 in-depth interviews with city break visitors to Dublin. The purpose of this phase was to uncover insights from 'thick descriptions,' in the visitors' own words, in relation to their travel behaviour. These thick descriptions, as outlined by Geertz (1973), consist of detailed information about the process being examined from the viewpoints of the participants in the process. Drawing on data from Phase One, it was possible to develop an accurate sampling frame based on the characteristics of city break visitors to Dublin. The interviews were carried out at three locations around the city, at 
different times of the year, and at different times of the week. Interviews lasted between 25 minutes and 1 hour and were recorded. They were later transcribed and subsequently analysed using a qualitative approach involving data reduction, data display, and conclusion drawing/verification, as outlined by Miles and Huberman (1994). From this, a number of themes connected to people's travel behaviour emerged. The detailed information collected from the interviews consisted of data not just relating to the interviewee's city break but also their last main holiday. This allowed direct comparisons to be made in relation to people's wider trip taking behaviour.

In analysing the results from both phases of the research a number of distinctive features of city break travel became apparent. These were characteristics that emerged from both the quantitative and qualitative data sets and were categorised into 5 main areas. These are conveniently referred to as the 5 Ds of city break travel. Although primarily relating to the situation in Dublin they are reflective of city break travel in a wider context also.

\section{THE 5 Ds OF CITY BREAK TRAVEL}

The five characteristics (5 Ds) will now be discussed in an effort to shed light on the factors that make city break trips distinctive as a type of holiday. The five specific features are; Duration, Distance, Discretionary nature, Date flexibility and Destination travel party.

\section{Duration}

The first distinctive feature relates to the length of the trip. The findings in this research support the common view (Law, 2002; Trew and Cockerell, 2002) that city breaks generally consist of short stay trips. The results from Phase One show how city break 
visitors stay for noticeably shorter periods compared to other leisure tourists - 55\% stated their trip consisted of 3 nights or less, compared to just $6 \%$ for non city break holidaymakers.

It would be wrong however to assume that all city breaks are short breaks, clearly they are not. Some people come on city only holidays for longer durations, and indeed, there is evidence to suggest that longer city break trips are growing faster than average (Trew and Cockerell, 2002). However, in general, the findings show most city breaks being short, usually 3 nights or less. The results point to three main explanations for this. Firstly, city breaks tend to be secondary trips often supplementing a person's main holiday. In this regard they tend to be of a shorter duration as they are complementing rather than replacing a bigger trip. Secondly, as Law (1993) and Burtenshaw et al., (1991) point out, many people are able to see and experience what they want, in most cities, in a few days. This was confirmed in the Phase Two interviews where a number of people, although generally indicating their approval with Dublin as a destination, also pointed out that a few days or a weekend in the city was adequate to satisfy their city break requirements. 'It's a nice city and we've really enjoyed it but in the end of the day the three days is enough, we've seen what we wanted to see' (James, London).

This was echoed by people who visited the city for concerts or sports games which, by their nature, tend to be short term events. The third reason relates to the international trend towards shorter, but more frequent leisure trips. This trend has been one of the most significant developments in European travel in recent years and the city break phenomenon is testimony to this. Cities, as destinations, lend themselves easily to short break travel. For time pressed travellers, cities can be reached directly, reducing or 
eliminating transfer issues commonly associated with longer holidays. In addition, attractions and amenities are generally clustered or located close together, resulting in little time spent moving around the destination. Thus, for many people, cities represent the ideal short break holiday destination.

\section{Distance}

The second distinctive characteristic relates to the distance people travel to take such holidays. City break visitors tend to come mostly from nearby source markets. This fact is very much evident in Dublin where $80 \%$ of the city break market comes from Britain, a statistic that is much higher than the overall figure for British holidaymakers into Dublin (50\%). Urban tourism demand in many other European cities follows a similar trend. Because of the limited duration of most city break trips people don't like to spend much time getting to and from the destination. The increased availability of low cost point to point flights has improved matters greatly in this regard. Page (2002) refers to the development of regional air services outside the main national gateways as having contributed significantly to the rise of secondary urban trips. Cheap frequent access from a range of airports in neighbouring markets has been a key feature of most city break destinations. For example, the number of air routes into Dublin is highest from Britain. Ryanair alone flies to 17 different British airports from Dublin. The impact of this cheap air access is reflected in the holiday arrivals statistics, which show growth in air travel to Dublin far exceeding that of ferry services. As Table 1 shows there has been a significant shift in mode of entry by British visitors over the period 1997 to 2007 . The figures highlight a swing of $36 \%$ from sea to air transport. Low cost airlines have had a huge influence on this shift. 


\section{Table 1}

Clearly for time pressed city break visitors, fast, direct air access is a hugely attractive option. In Dublin's case this is reflected in the large number of city breakers coming from Britain. For these visitors, Dublin represented one of the most easily accessible overseas city destinations available to them.

'It was cheaper to come here than what it is to go to my work, and it was quicker. I mean it takes me an hour-and-a-half to go to my work, whereas I mean I couldn't believe it, it was 50 minutes. We left home at 7 a.m. in the morning and arrived here at 7.52 a.m. I mean it's incredible, I couldn't believe it for 70p each way - I mean that's much less than I pay going to work. Although I know the taxes bring it up but still it's amazing' (Ruth, Glasgow).

\section{Discretionary nature}

Another significant feature of city breaks is the discretionary nature of the trips. During the visitor interviews respondents were asked about their trip taking patterns in the previous year in order to examine how the city break fitted in with other trips (if any) they had taken. The findings showed that people had generally taken the city break as an additional trip to their main holiday. There were only a few cases where the Dublin city break was considered the principal, or indeed only, holiday of the year. This supports Page's (2002, p.121) assertion that 'many urban holiday trips are secondary trips, complementing the traditional summer-long annual holidays which are coastal-based.' In most cases the trip was viewed as a discretionary break, and for some an opportunistic 
one. This is reflected in the short decision time that was evident with many of the trips. The survey results show almost $60 \%$ of city breakers booked their accommodation less than 4 weeks before their trip compared with $37 \%$ of non city break holidaymakers, indicating what Swarbrooke and Horner (2007, p. 77) note as 'the increasing popularity of last minute purchases of tourism products.' For most people, city breaks were conceived and acted on in a relatively short period of time, with the internet playing a significant role in this behaviour.

The influence of situational factors was also found to contribute to the discretionary nature of city break trip taking. These are factors which Belk (1975, p.158) refers to as 'particular to a time and place of observation ... and which have a demonstrable and systematic effect on current behaviour.' Evidence from the interviews shows that the genesis of many city break ideas can be traced to particular circumstances that people faced, or situations that arose in people's lives. These proved to be quite diverse, however, all had a similar outcome, in that, taking a city break was considered an appropriate response to the particular situation they faced. For example, one interviewee explained how a family bereavement was the catalyst for his trip to Dublin:

'Well to tell you the truth it came about because I lost my brother a couple of weeks ago ... I just needed to get away, clear my head like. I went to a travel agent and just said I need to get away for a couple of days - and so she suggested here.'

In some cases the city break was organised by a third party, and as such the decision often came down to a simple question - 'do I join this trip or not?' Once this decision was 
made respondents often had very little other input into the trip, except to participate. This usually differed from people's main holiday situation where the initial generic decision of whether or not to take a trip was, in many cases, already made. For most people the main holiday was an annual ritual, therefore the decision making tended to focus less on whether to go and more on where to go. By contrast city breaks were usually less predetermined and as such the decision making was more discretionary in nature. The decision process did not tend to follow distinctive stages as commonly outlined in the tourism literature. For example, the conventional view is that people first decide on whether or not to take a trip - what Hodgson (1983) calls first order questions - and then subsequently choose what kind of trip to take (second order questions). However, for many city breakers these decisions were made concurrently. In other words, people often came upon a good city break deal or were introduced to one and decided to 'go for it,' and as such were making first and second order decisions simultaneously. 'I saw the special offer for the flight and that I suppose started me thinking. And then because we had free time and no real commitments we decided why not' (Fred, Bristol).

This reflects impulsive or opportunistic decision making behaviour that is very much linked to the discretionary nature of the trips. It also shows the strength of special offers and deals when discovered by people at particular times. Advertisements for cheap flights, in particular, were found to stimulate demand in a number of cases. 


\section{Date flexibility}

The fourth distinctive feature of city break travel relates to the lack of seasonal bias associated with the trips. Table 2 shows findings from the survey that highlight the difference in arrival patterns between city break and non city break visitors to Dublin.

\section{Table 2}

Such a demand pattern can be partly attributed to what Burtenshaw et al. (1991) point out as the relatively minor role weather plays in city based tourism. The findings show $17 \%$ of city breakers to Dublin arrived during winter months compared to just $4 \%$ of non city break holidaymakers. However besides weather the disparity in arrival patterns can also be attributed to other factors. For example, the secondary nature of city breaks means most are taken outside of peak periods. Sometimes these trips are centred around events such as concerts, sports games, and exhibitions. These are generally spread throughout the year and as such the city break visitors who attend them contribute to the development of a year round city destination.

'Yes, I suppose the concert was the main reason for coming (to Dublin), we are big fans and we did not want to miss it' (Christina, Rotterdam).

This non seasonal demand pattern is a crucial feature and one that makes city breakers an attractive market for urban tourism businesses. 


\section{Destination travel party}

The final characteristic of city break travel concerns the composition of the travelling unit. One of the most interesting findings in this regard was the small number of travel parties that included children. Most people either travelled with a partner or with a group of friends. The survey results highlight this, with $60 \%$ of city break visitors travelling to Dublin with a spouse or a partner and $19 \%$ travelling with a group of friends. By contrast just $13 \%$ came with their family (including children). These results concur with previous studies which show a high proportion of urban tourists travel without children (Flanagan and Dunne, 2005; British Tourist Authority, 1988; Trinity Research, 1989). Three main factors emerged as the principal reasons why children are not well represented in city break travel parties. Firstly, a high proportion of city breakers did not have children. The findings show that many of the groups were made up of single people travelling together (friends, affinity groups, stag/hen parties, etc), or couples who either did not have children or whose children had left home (empty nesters). For all these people, ease of mobility was a key factor in their choice of trip. They were not tied to the school calendar and as such were more flexible with their travel plans. This allowed them to avail of special travel offers which tend to be more plentiful and financially rewarding during school term. Childless travellers can also usually take trips without a lot of preplanning, which means they can often make decisions more speedily and spontaneously. For such people city breaks represent a very attractive travel option.

The second reason relates to people who had children at home, but who used the city break trip to escape the stresses and pressures of parenting. This was particularly evident 
in the interviews where a number of couples described their trip to Dublin as a chance to take a break from their children.

'We have a young son - he's one and a half and he's into everything at the moment. Jane's mother took him for these few days. It's great to just get the break' (Brian, Nottingham).

A city break was seen as ideal in many ways for this purpose - the short stay nature of the trips along with the ease of access made travelling easier in terms of arranging childminding. Interestingly, these people saw the city break as an adult focused holiday centred on themselves. By contrast, the main holiday was seen as a chance to spend time with their children.

The third reason for the lack of children relates to the child-unfriendly perception of cities as destinations. A few of the interviewees commented on the lack of things to do for kids in Dublin or the difficulty in keeping them amused, while others claimed they would never bring their children to a city for a holiday.

\section{CONCLUSION}

Distinguishing between the types of trips people take can be a very useful exercise for tourism researchers. Such an approach focuses on the nature of the trip - its principal characteristics - and as such offers potentially more valuable visitor behaviour data than other approaches. By studying the different characteristics of various holidays, a greater understanding of trip taking behaviour is possible. Certainly this is the case with city 
breaks, where up to now little empirical data in relation to the nature of these trips has existed. As the changing structure of trip taking by Europeans continues to influence the growth of city breaks, the need for up to date information on this visitor market has become more pressing. This study has shown that the international city break trip has a number of distinguishing characteristics. These are encapsulated in five main features ( 5 Ds), duration, distance, date flexibility, discretionary nature, and destination travel party. The findings in this regard show city break trips to be generally short in duration (usually less than three nights) involving mostly short haul flights from neighbouring countries. In addition, they tend to be secondary trips that people often use to supplement a main holiday. They are also likely to be taken throughout the year and are mostly made up of couples or groups of friends.

Uncovering these characteristics provides a better understanding of city break trips and in particular their distinctiveness compared to other types of holidays. The ability of city breaks to provide a quick, short escape from the routine of daily life shows them to be fulfilling a significant role in today's cash rich, time poor society. In addition, the findings highlight some interesting themes in relation to the role of a holiday particularly in terms of its social function. For example, some trips were viewed as opportunities to build on personal relationships, often between partners, while others provided a more hedonistic function in which the holiday was viewed as a chance to regress or behave in a manner that would be socially out of character in the home environment. Such differences are interesting to observe and highlight the value of viewing holiday-taking in its wider social context. 
Looking forward, it is not certain if cities will continue to enjoy the appeal they do today. Given the increasingly negative economic environment that tourism faces it will be interesting to see if secondary trips such as city breaks manage to sustain the type of popularity they have experienced up to now. Further research into this area would be very useful. It would be particularly beneficial to see how people's perception of discretionary leisure travel changes in recessionary times. For example, will city breaks come to be viewed as an unnecessary luxury in harder economic times or is it possible people may turn to such trips as a cheaper alternative to their main holiday? In order to remain competitive in the years ahead city tourism suppliers will need to have a clear understanding of this important visitor group and be able to respond to the specific requirements they present. For this, comprehensive knowledge of city break travellers and the trips they engage in will be crucial.

\section{References}

Ashworth GJ, Tunbridge JE. 1990. The Tourist-Historic City Belhaven: London.

Ashworth GJ. 1992. Is there an urban tourism? Tourism Recreation Research 17(2): 3-8

Buckley PJ, Witt S. 1985. Tourism in difficult areas: case studies of Bradford, Bristol, Glasgow and Hamm. Tourism Management 6(3): 205-213.

Belk RW. 1975. Situational variables and consumer behaviour. Journal of Consumer Research 2: 157-67. 
Bieger JR, Laesser C. 2000. Segmenting travel situations on the basis of motivation and information collection by the traveller. Tourism Review 55 (2): 54-64.

Bloy D. 2000 An assessment of tourist motivations within a multiple holiday taking context. In Motivations, Behaviour and Tourist Types, Robinson M, Long P, Evans N, Sharpley R, Swarbrooke J (eds). Business Education Publishers: Sunderland; 27-44.

British Tourist Authority and English Tourist Board.1988. The Short Break Market. BTA: London.

Burtenshaw D, Bateman M, Ashworth GJ. 1991. The City in West Europe. Wiley: Chichester.

Flanagan S, Dunne G. 2005. Dublin Visitor Survey - Visitor Satisfaction and Attitudinal Analysis 2003. DIT: Dublin.

Freitag R. 2006. Using Market Intelligence in the Commercial World. Presented at $2^{\text {nd }}$ executive summit of the European Travel Commission - Symposium on market intelligence, Malta, October 4, 2006. Retrieved March 28, 2008. Available from

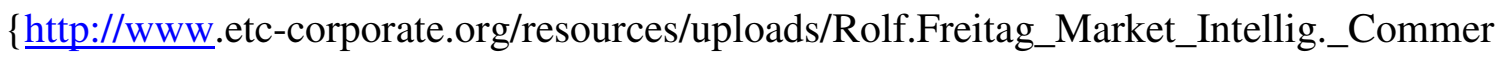
cial_World_onlineversion.pdf\} 
Geertz C. 1973. The Interpretation of Cultures. Basic Books: New York.

Hall CM, Page SJ. 2002. Managing Urban Tourism Pearson Education: Harlow.

Hodgson P. 1983. Research into the nature of the holiday choice process. In Proceedings of Seminar on the Importance of Research in the Tourist Industry, Helsinki, 1983 .

ESOMAR: Amsterdam.

Hudson S. 1999. Consumer behaviour related to tourism. In Consumer Behaviour in Travel and Tourism, Pizam A, Mansfeld Y (eds). Haworth Hospitality Press: New York; $7-32$.

Irish Tourism Industry Confederation. 2006. Regional Distribution of Holiday Bednights. ITIC: Dublin.

Jensen-Verbeke M. 1986. Inner city tourism, resources, tourists, and promoters. Annals of Tourism Research 13(1): 79-100.

Judd DR, Fainstein SS. 1999. The Tourist City. Yale University Press: New Haven, CT.

Law CM. 1993. Urban Tourism: Attracting Visitors to Large Cities. Mansell: London. 
Law CM. 2002. Urban Tourism: The Visitor Economy and the Growth of Large Cities. Continuum: London.

Mazanec C. 1997. International City Tourism: Analysis and Strategy. Pinter: London.

Miles MB, Huberman AM. 1994. Qualitative Data Analysis. Sage: California.

Miller WL, Crabtree BF. 1994. Clinical research. In Handbook of Qualitative Research, Denzin NK, Lincoln YS (eds). Sage: Thousand Oaks, California; 340-352.

Page S. 2002. Urban tourism: evaluating tourists' experience of urban places. In The Tourist Experience, Ryan C (ed.). Continuum: London; 112-136.

Page S. 1995. Urban Tourism. Routledge: London.

Pearce DG. 2001. An integrative framework for urban tourism. Annals of Tourism Research 28(4): 926-946

Selby M. 2004. Understanding Urban Tourism: Image, Culture and Experience. I.B. Tauris: London.

Sirakaya E, Woodside AG. 2005. Building and testing theories of decision making by travellers. Tourism Management 26(6): 815-832. 
Sung HH, Morrison AM, Hong GS, O'Leary JT. 2001. The effects of household and trip characteristics on trip types: A consumer behavioural approach for segmenting the U.S. domestic leisure travel market. Journal of Hospitality and Tourism Research 25(1): 4668.

Swarbrooke J, Horner S. 2007. Consumer Behaviour in Tourism. ButterworthHeinemann: Oxford.

Trew J, Cockerell N. 2002. The European market for UK city breaks. Insights 14(58): $85-111$.

Trinity Research. 1989. The UK Short Break Holiday Market. Trinity Research.

Wöber K. 2002. City Tourism 2002. Springer Verlag: Vienna. 
Table 1

Route of Entry \% from Britain (2007 v 1997)

\begin{tabular}{|l|l|l|l|}
\hline & 1997 & 2007 & \% Change \\
\hline Air & $39 \%$ & $75 \%$ & $+36 \%$ \\
\hline Sea & $61 \%$ & $25 \%$ & $-36 \%$ \\
\hline
\end{tabular}

Source: Fáilte Ireland Market Trends (Britain)

Table 2

Timing of Visit by Type of Holidaymaker

\begin{tabular}{|l|c|c|}
\hline & $\begin{array}{c}\text { City Break } \\
\text { Holidaymaker }\end{array}$ & $\begin{array}{c}\text { Non City Break } \\
\text { Holidaymaker }\end{array}$ \\
\hline Winter & $17.2 \%$ & $4.3 \%$ \\
\hline Spring & $23.2 \%$ & $14.9 \%$ \\
\hline Summer & $34.0 \%$ & $43.3 \%$ \\
\hline Autumn & $25.6 \%$ & $37.5 \%$ \\
\hline Total & $\begin{array}{c}100 \% \\
(n=379)\end{array}$ & $\begin{array}{c}100 \% \\
(n=416)\end{array}$ \\
\hline
\end{tabular}

